\title{
Trakya Bölgesindeki Bal Arılarında (Apis mellifera L.) mtDNA 16S rDNA ve ND5 Genleri Analizi
}

\author{
Ayşe GÜDER ${ }^{1}$, Raziye IŞIK² ${ }^{2}$ Fulya ÖZDíL ${ }^{2 *}$ \\ ${ }^{1}$ Namık Kemal Üniversitesi, Fen Bilimleri Enstitüsü, Tarımsal Biyoteknoloji Anabilim Dalı, Tekirdağ \\ ${ }^{2}$ Namık Kemal Üniversitesi, Ziraat Fakültesi, Tarımsal Biyoteknoloji Bölümü, Tekirdağ \\ *Illetişim (correspondence): e-posta: fozdil@nku.edu.tr; Tel: +90 (282) 2502233 \\ Gönderim tarihi (Received): 11 Ekim 2017; Kabul tarihi (Accepted): 14 Kasım 2017 \\ ** Bu çalışma Ayşe Güder’ in Yüksek Lisans Tezinden üretilmiştir.
}

\section{$\ddot{\mathbf{O z}}$}

Bu çalı̧̧mada, Türkiye'nin Trakya bölgesinde bulunan bal arısı populasyonlarında genetik varyasyon mitokondriyel genomda 16S rDNA ve ND5 gen bölgeleri kullanılarak araştırılmıştır. PCR-RFLP ve DNA dizi analizi yöntemlerinden yararlanılarak 16S rDNA ve ND5 gen bölgeleri $D r a I, M b o I I$ ve $S w a I$ restriksiyon enzimleri ile incelenmiştir. Trakya bölgesinin Tekirdağ, Edirne, Kırklareli illeri ile Çanakkale ve Gökçeada'nın farklı yörelerinden olmak üzere toplam 100 adet işçi arı örneği materyal olarak kullanılmıştır. $\mathrm{Bu}$ çalışmada, 16S rDNA ve ND5 gen bölgelerinin DraI ve SwaI restriksiyon enzimleri ile kesiminde iki farklı haplotip elde edilmiştir. 16S rDNA/DraI kesimi bakımından Tip 1 haplotipinde 6 kesim noktası tespit edilmiş ve 315, 212, 116, 116, 92, 70 ve 44 bç'lik kesim profili elde edilmiştir. Tip 2 haplotipinde ise, $\mathrm{C} \rightarrow \mathrm{T}$ transisyonu sonucu 705. pozisyonda meydana gelen nokta mutasyonu sonucu ilave bir kesim noktası daha oluşmuş ve bu haplotipte 8 bantlık kesim profili elde edilmiştir $(215,212,116,116$, 100, 92, 70 ve 44 bç). 16S rDNA/SwaI bakımından Tip 1 haplotipinde iki kesim noktası sonucu 359, 324 ve 282 bç’lik bant profili tespit edilmiş, aynı gen bölgesinin 196. nükleotidinde meydana gelen $\mathrm{A} \rightarrow \mathrm{T}$ transversiyonu sonucu yeni bir kesim noktası daha oluşmuş ve 359, 324, 195 ve 87 bç'lik 4 bant veren kesim profili elde edilmiştir. Fakat bu bölgenin MboII restriksiyon enzimi ile kesimi sonucunda tüm örneklerde 16S rDNA/MboII bakımından tek tip haplotip belirlenmiştir. ND5 gen bölgesinde ise sadece $\mathrm{DraI}$ restriksiyon enzimi ile kesim sonucunda varyasyon elde edilmiştir. ND5/DraI kesimi bakımından Tip 1 haplotipinde 440, 270 ve 112 bç'lik bant profili elde edilirken, aynı gen bölgesinin 383. pozisyonda meydana gelen $\mathrm{T} \rightarrow \mathrm{C}$ transisyonu sonucu DraI restriksiyon enzimi kesim noktası kaybolmuş ve 552 ve 270 bç'lik 2 banttan oluşan kesim profili elde edilmiştir. ND5 bölgesinin $M b o I I$ ve $S w a I$ restriksiyon enzimleri ile kesiminde varyasyon bulunmamış ve tüm örneklerde tek tip haplotip elde edilmiştir.

Anahtar kelimeler: Apis mellifera L., mtDNA, 16S rDNA, ND5, PCR-RFLP, Trakya Bölgesi

\section{Analysis of mtDNA 16S rDNA and ND5 Genes in Thracen Honey Bees of Turkey (Apis mellifera L.)}

\begin{abstract}
In this study, it was aimed to determine the genetic variation among honey bee populations in Thrace region of Turkey using $16 \mathrm{~S}$ rDNA and ND5 gene regions. DNA sequencing and PCR-RFLP was done by DraI, MboII and SwaI restriction enzymes. A total of 100 worker honey bees samples were used from different regions of Tekirdağ, Edirne, Kırklareli, Çanakkale provinces and Gökçeada Island. In this study, two different haplotypes were identified with DraI and SwaI restriction enzymes in 16S rDNA and ND5 gene regions. Seven bands of 315, 212, 116, 116, 92, 70 and 44 bp were observed in Type 1 haplotype in terms of 16S rDNA/DraI restriction. In Type 2 haplotype, there is an additional restriction site at position 705 which is a result of $\mathrm{C} \rightarrow \mathrm{T}$ transition and this haplotype gave 8 band pattern $(215,212,116,116,100,92,70$ and $44 \mathrm{bp})$. For the $16 \mathrm{~S} \mathrm{rDNA} / \mathrm{SwaI}$ restriction, 3 different bands of 359, 324 and 282 bp was determined in Type 1 haplotype. In Type 2 haplotype, there is an additional restriction site at position 196 which is a result of $\mathrm{A} \rightarrow \mathrm{T}$ transition and this haplotype gave 4 band profile of 359, 324, 195 and 87 bp bands. However, one haplotype was identified in all samples for 16S rDNA/MboII. For the ND5/DraI restriction, 3 bands of 440, 270 and $112 \mathrm{bp}$ was detected in Type 1 haplotype. Single nucleotide change at position 383 ( $\mathrm{T} \rightarrow \mathrm{C}$ transition) resulted the loss of the DraI recognition site in ND5 gene region. Thus, 2 bands of 552 and 270 were observed. No restriction site variation was found in ND5 region with the restriction enzymes MboII and SwaI.
\end{abstract}

Keywords: Apis mellifera L., mtDNA, 16S rDNA, ND5, PCR-RFLP, Thrace region 


\section{Giriş}

Batı bal arısı (Apis mellifera L.), yüksek adaptasyon kabiliyetinden dolayı dünyanın pek çok bölgesine yayılmış ve en yaygın yetiştiriciliği yapılan arı türüdür. Günümüzde bulunduğu bölgelerin ekolojik koşullarına uyum sağlamış çok sayıda bal arısı coğrafik ırkı (alt tür) oluşmuş ve bu irklar içerisinde de farklı ekotipler meydana gelmiştir.

Bal arısı türleri içerisinde en fazla coğrafi varyasyona sahip olan Batı bal arısının (Apis mellifera L.), dünya üzerinde temelde 4 soya ayrlan toplam 27 alt türü olduğu bildirilmektedir (Ruttner 1988, Sheppard ve ark. 1997). Türkiye'de ise kuzey doğuda Kafkas bal arısının (A. m. caucasica), güney doğuda İran bal arısının (A. m. meda) var olduğu bildirilmekte bunun dişında kalan bölgelerde ise Anadolu arısının (A. m. anatoliaca) yayılış gösterdiği ifade edilmektedir (Ruttner 1988). Son yıllarda morfometrik çalışmalar ile moleküler çalışmaların birlikte değerlendirilmesi sonucu güneyde Hatay ili civarında Suriye arısının (A. m. syriaca) var olduğu ve Trakya Bölgesi'nde ise Karniyol arısının (A. m. carnica) bulunduğu bildirilmektedir (Smith ve ark. 1997, Palmer ve ark. 2000, Kandemir ve ark. 2006). Bu beş alt türe ilave olarak da pek çok ekotip (Muğla, Yığıllca, Gökçeada vb.) bulunmaktadır.

Trakya Bölgesinde Karniyol arısının var olduğuna dair ipuçları mitokondriyel genomda çalışılan sitokrom C oksidaz I ile II lokusları arasında (CoxI-CoxII arası) ikinci $X b a \mathrm{I}$ kesim noktasının tespit edilmesi ile ortaya konmuştur (Smith ve ark. 1997, Palmer ve ark. 2000). Daha önce yapılan çalışmalarda Avusturya ve Balkanlar'dan alınan A. m. carnica alt türünü temsil eden örneklerde ikinci bir XbaI kesim noktası bulunduğu bildirilmiștir (Smith ve Brown 1990, Meixner ve ark. 1993). CoxI gen bölgesinde ikinci bir XbaI kesim noktası bulunan ve bulunmayan arı örneklerinin bu gen bölgesinin nükleotid dizilimi incelenmiş ve farklılığa sadece tek bir nokta mutasyonunun sebep olduğu belirlenmiştir. İkinci bir XbaI kesim noktası bulunan arı örneklerinde TCTAGA şeklinde olan nükleotid diziliminin, bulunmayan örneklerde ise TTTAGA şeklinde olduğu belirlenmiștir. Türkiye'nin farklı yörelerinden alınan bal arısı örneklerinde ilave CoxI/XbaI kesim noktası tespit edilmezken sadece Trakya'dan alınan örneklerde ilave CoxI/XbaI kesim noktası bulunduğu bildirilmiştir (Smith ve ark. 1997, Palmer ve ark. 2000, Ünal ve Özdil 2017). Bu kesim noktası temelinde Trakya Bölgesinde Karniyol arısı orijinli farklı bir alt türün veya ekotipin var olduğu ifade edilmektedir.

Son yıllarda Trakya bölgesinde tüm Türkiye'deki bal arısı alt türlerinden farklı bir alt türün var olduğuna dair bulgular artmaktadır. Bu çalışmada T.C. Gıda Tarım ve Hayvancılık Bakanlığı tarafindan yerli arı gen kaynaklarının korunması amacıyla izole bölge oluşturulan Kırklareli ilindeki bal arısı populasyonları da dâhil olmak üzere Tekirdağ, Kırklareli, Edirne, Çanakkale illeri ile Gökçeada'dan bal arısı örnekleri alınarak mitokondriyel genomda varyasyon araştırılmıştır.

\section{Materyal ve Yöntem}

Araştırmanın materyalini daha önce TÜBİTAK 1140883 nolu proje kapsamında toplanan bal arıları oluşturmaktadır. Tekirdağ, Kırklareli, Edirne, Çanakkale ve Gökçeada'dan olmak üzere toplam 100 adet bal arısı ile çalışılmıştır. Genomik DNA izolasyonu, Hall (1990)'ın tanımladığı fenol-kloroform ekstraksiyon yöntemine göre yapılmıştır.

DNA izolasyonunu takiben hedeflenen mitokondriyel DNA 16S rDNA ve ND5 gen bölgelerinin çoğaltılması amacıyla PCR işlemi gerçekleştirilmiştir. Kullanılan primerler ve restriksiyon enzimleri ile ilgili bilgiler Çizelge 1'de verilmiştir.

Çizelge 1. mtDNA 16S rDNA ve ND5 genleri için kullanılan primerler, restriksiyon enzimleri ve kaynaklar

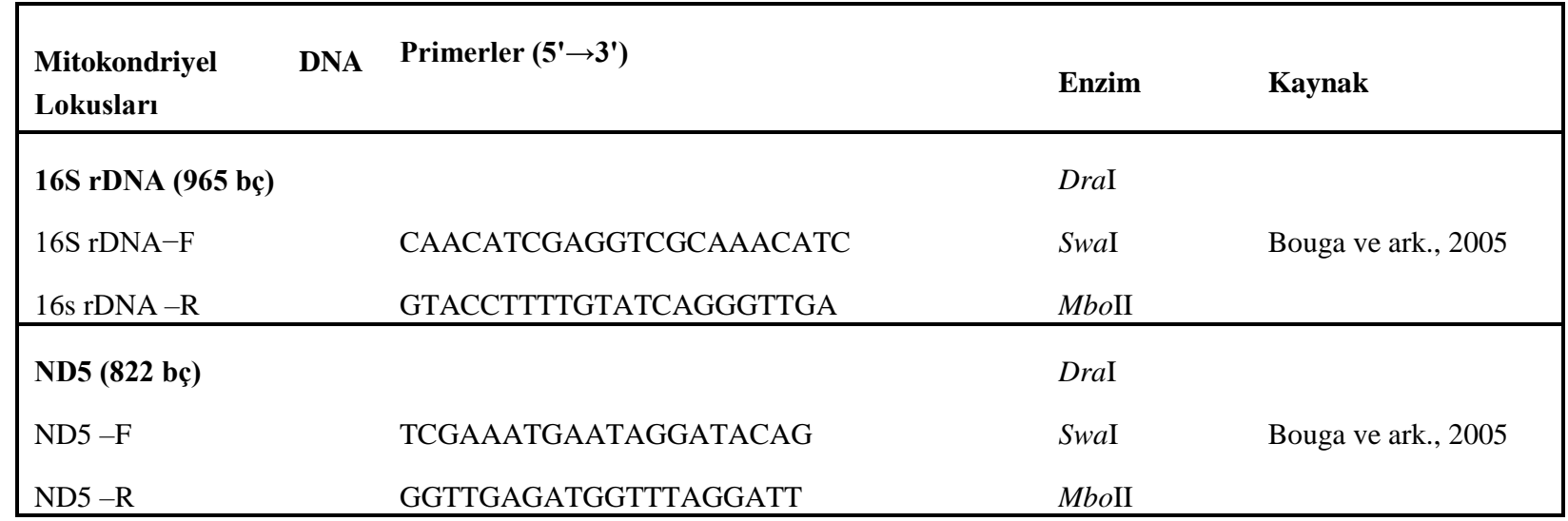


16S rDNA ve ND5 gen bölgelerinin çoğaltılması için hazırlanan PCR reaksiyonu; $25 \mu \mathrm{l}$ karışım, 50-100 ng genomik DNA, her primerden $0.5 \mu \mathrm{M}, 1 \mathrm{X}$ PCR buffer, $2 \mathrm{mM} \mathrm{MgCl}_{2}, 2 \mathrm{mM}$ dNTP ve $1 \mathrm{U}$ Taq DNA Polimeraz (Thermo Fisher, 10342020) şeklinde hazırlanmıştır. PCR koşullarının oluşturulmasında kullanılan primerlerin bağlanma sıcaklıkları 16S rDNA lokusu için $55^{\circ} \mathrm{C}$, ND5 lokusu için $50^{\circ} \mathrm{C}$ olarak belirlenmiştir.

Mitokondriyel genomda 965 baz çifti uzunluğundaki 16S rDNA ve 822 baz çifti uzunluğundaki ND5 gen bölgeleri PCR ürünleri DraI, SwaI ve MboII restriksiyon enzimleri (ER0221, ER1241 ve ER0821, Thermo Fisher Scientific) ile protokole uygun olarak inkübe edilmiştir. Restriksiyon enzimleri ile muamele sonrası elde edilen ürünler \% 2.5'lik agaroz jel elektroforezi ile sabit voltajda 90 dakika yürütülmüştür.

$\mathrm{Bu}$ çalışmada PCR-RFLP yöntemi ile elde edilen genotiplerin doğrulanması amacıyla DNA dizi analizi işlemi (ABI 3500XL Genetic Analyzer, USA), ticari bir firmadan hizmet alımı şeklinde gerçekleştirilmiştir (MedSanTek Laboratuvar Malzemeleri San. ve Tic. Ltd. Şti). Dizi analizi sonuçları MEGA7 (Molecular Evolutionary Genetics Analysis version 7.0) programında değerlendirilerek UPGMA dendogramı çizilmiştir.

\section{Bulgular ve Tartışma}

Bu çalışmada Trakya Bölgesi'nden örneklenen bal arısı populasyonlarında iki farklı gen bölgesi (16S rDNA ve
ND5) ile çalışılmıştır. Bu gen bölgeleri DraI, MboII ve SwaI restriksiyon enzimleri ile PCR-RFLP analizine tabi tutulmuş ve varyasyon bulunan haplotipler DNA dizi analizi ile incelenmiştir.

\section{6s rDNA Gen Bölgesinin PCR ile Çoğaltılması ve Enzim Kesim Sonuçlart}

Trakya Bölgesi'nde çalışılan bal arısı populasyonlarında 16S rDNA gen bölgesinin DraI enzimi ile kesilmesi sonucunda 2 farklı haplotip belirlenmiştir.

16S rDNA/DraI kesimi bakımından yaygın bulunan haplotip olan Tip 1 haplotipinde 6 kesim noktasi tespit edilmiş ve $315,212,116,116,92,70$ ve 44 bç'lik kesim profili elde edilmiştir (Şekil 1). Gökçeada/ Zeytinlikköy'den alınan bir örnekte farklı bir kesim profili tespit edilmiş olup bu haplotip Tip 2 olarak adlandırılmıştır. $\mathrm{Bu}$ haplotip DNA dizi analizi ile incelenmiş ve bu çalışmada çoğaltılan 965 bç büyüklüğünde $16 \mathrm{~S}$ rDNA gen bölgesinin 705 . pozisyonda meydana gelen nokta mutasyonu $(\mathrm{C} \rightarrow \mathrm{T}$ transisyonu) ilave bir kesim noktası daha oluşturmuştur. $\underline{\text { CTTAAA }}$ şeklinde olan DNA dizisi TTTAAA olarak yeni bir DraI kesim noktası oluşturmuştur. 16S rDNA/DraI kesimi bakımından elde edilen Tip 2 haplotipinde 215, 212, 116, $116,100,92,70$ ve 44 bç olmak üzere 8 bantlık kesim profili elde edilmiştir. Gökçeada/Zeytinlikköy'den alınan bir örneğin dışında tüm örneklerde Tip 1 haplotipi bulunmuştur (Şekil 1).

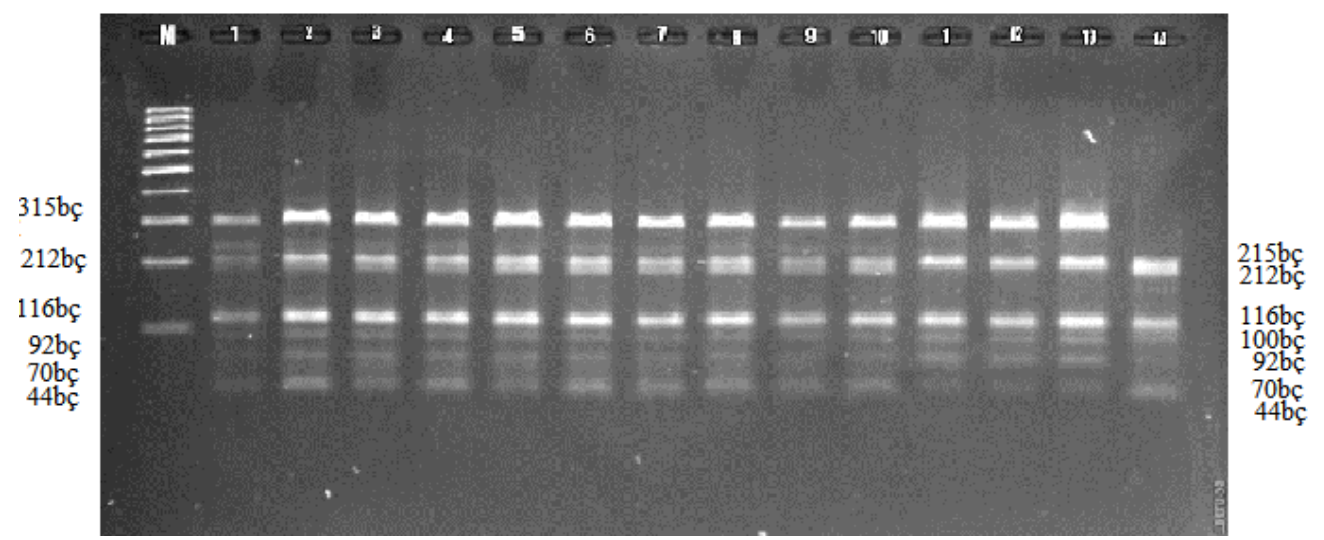

Şekil 1. 16S rDNA gen bölgesinin DraI restriksiyon enzimi kesim sonucu.

1-13. örnekler: Tip 1 haplotipi, 14. örnek: Tip 2 haplotipi, M: invitrogen ${ }^{\mathrm{TM}} 100$ bp DNA Ladder. (1-3. örnekler: Tekirdağ, 4-7. örnekler: Kurklareli, 8-10. örnekler: Edirne, 11-12. örnekler: Çanakkale, 13-14. örnekler: Gökçeada'dan alınmıştır.)

Bouga ve ark. (2005), Yunanistan ve Kıbrıs’a özgü bal arısı örneklerinde 16S rDNA gen bölgesinin DraI restriksiyon enzimi ile kesimi sonucunda tek bir kesim noktası olduğunu ve 557, 407 bç olmak üzere iki bant elde edildiğini bildirmişlerdir. Kekeçoğlu ve ark.
(2009), Türkiye bal arısı populasyonlarında aynı gen bölgesi ile çalışmışlar ve $16 \mathrm{~S}$ rDNA/DraI kesimi sonucunda iki haplotip (A: 557 bç, 407 bç ve B: 964 bç) belirlemişlerdir. Ivonova ve ark. (2010), Bulgaristan arı populasyonlarında aynı gen bölgesinde tek haplotip (B: 
964 bç) belirlemişlerdir. Özdil ve ark. (2012), Türkiye'den ayrıntılı olarak İç Anadolu Bölgesi'nden örnekledikleri bal arılarında yaptıkları çalışmalarında 16S rDNA/DraI bakımından iki farklı haplotip (C: 315, 212, 116, 116, 92, 70, 43 bç ve D: 358, 212, 116, 116, 92, 70 bç) belirlemişlerdir. Yaptığımız çalışmada Özdil ve ark. (2012)'de bildirilen C haplotipi görülmüştür. C haplotipine ilave olarak Gökçeada/Zeytinlikköy'den alınan örnekte 16S rDNA gen bölgesinin 705 . pozisyonda meydana gelen nokta mutasyonu sonucu yeni bir DraI kesim noktası oluşmuş ve 215, 212, 116, $116,100,92,70$ ve 44 bç'lik kesim profili ilk kez bu çalışmada ortaya konmuştur (Şekil 1).

Trakya bal arısı populasyonlarında 16S rDNA gen bölgesinin SwaI restriksiyon enzimi ile kesilmesi sonucunda 2 farklı haplotip tespit edilmiştir. Yaygın bulunan Tip 1 haplotipinde 359, 324 ve 282 bç'lik 3 bantlık kesim profili elde edilmiştir. Söz konusu çalışmada Tekirdağ/Çerkezköy'den alınan iki örnekte farklı bir kesim modeli tespit edilmiş olup bu haplotip Tip 2 olarak ile ifade edilmiştir. Tip 2 haplotipinde 359, 324, 195 ve 87 bç'lik bant profili elde edilmiştir. Tip 2 haplotipinin DNA dizi analizi sonucu 16S rDNA gen bölgesinin 196. nükleotidinde $\mathrm{A} \rightarrow \mathrm{T}$ transversiyonu meydana gelmiş ve ATTÁAAAT şeklinde olan DNA dizisi, ATTIAAAAT olduğundan yeni bir SwaI kesim noktası oluşturmuştur. Bu nokta mutasyonu sonucu Tip 2 haplotipinde 359, 324, 195 ve 87 bç'lik 4'lü bant profili görülmüştür. Çalışılan diğer tüm örnekler Tip 1 haplotipinde bulunmuştur (Şekil 2).

16S rDNA gen bölgesinin MboII restriksiyon enzimi ile kesimi sonucunda 635 ve 330 bç'lik 2 banttan oluşan kesim profili elde edilmiştir. Çalışılan tüm örneklerde bu lokusta aynı kesim profili ve tek bir haplotip belirlenmiştir (Şekil 3).

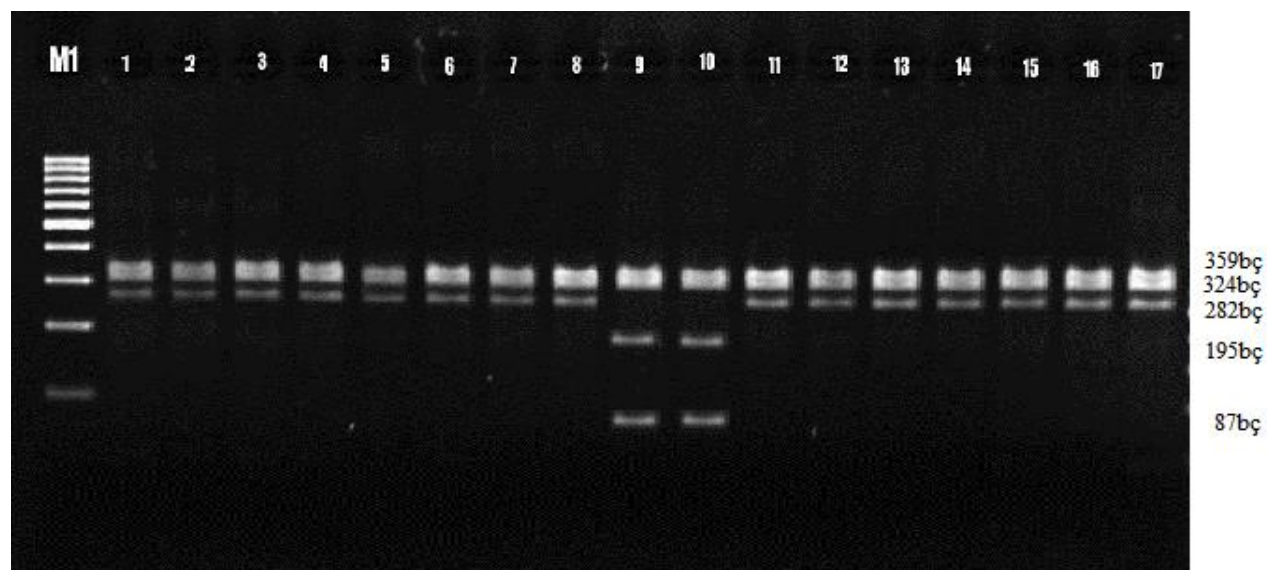

Şekil 2. 16S rDNA gen bölgesinin SwaI restriksiyon enzimi kesim sonucu.

1-8. ve 11-17. örnekler: Tip 1 haplotipi, 9-10. örnekler: Tip 2 haplotipi (Tekirdağ/Çerkezköy), M: invitrogen ${ }^{\mathrm{TM}} 100$ bp DNA Ladder. (1-4. örnekler: Edirne, 5-8. örnekler: Kırklareli, 9-12. örnekler: Tekirdağ, 13-15. örnekler: Çanakkale, 16-17. örnekler: Gökçeada'dan alınmıştır.)

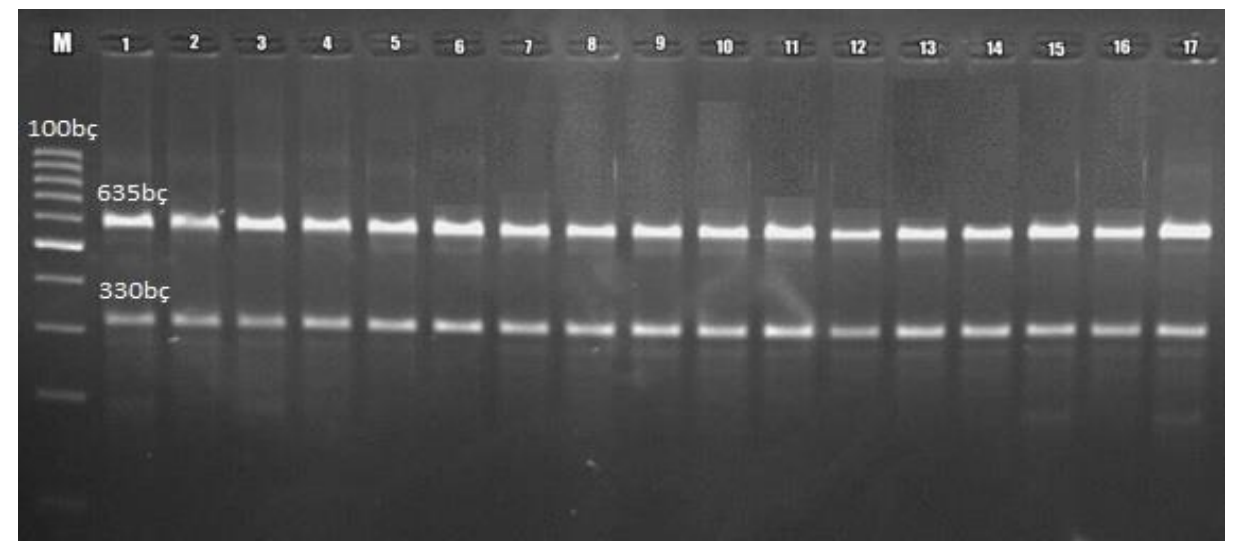

Şekil 3. $16 \mathrm{~S}$ rDNA gen bölgesinin MboII restriksiyon enzimi kesim sonucu.

1-14. örnekler: Tip 1 haplotipi, M: invitrogen ${ }^{\mathrm{TM}} 100$ bp DNA Ladder. (1-4. örnekler: Tekirdağ, 5-8. örnekler: Kırklareli, 9-12. örnekler: Edirne, 13-15. örnekler: Çanakkale, 16-17. örnekler: Gökçeada'dan alınmıştır.) 


\section{ND5 Gen Bölgesinin PCR ile Çoğaltılması ve Enżim Kesim Sonuçlart}

Trakya Bölgesi'nde çalışılan bal arısı populasyonlarında 822 bç büyüklügüünde olan ND5 gen bölgesinin DraI restriksiyon enzimi ile kesilmesi sonucunda 2 farkl haplotip belirlenmiştir. Yaygın bulunan Tip 1 haplotipinde 440, 270 ve 112 bç'lik kesim profili tespit edilmiştir. Söz konusu çalışmada Edirne/Meriç’ten alınan bir örnekte 552 ve 270 bç'lik farklı bir bant profili belirlenmiş olup bu haplotip, Tip 2 olarak adlandırılmıştır. ND5/DraI gen bölgesinde tespit edilen iki haplotip arasında yalnızca tek bir nokta mutasyonu olduğu görülmüştür. Referans dizisine göre ND5 gen bölgesinin 383. pozisyonda $(\mathrm{T} \rightarrow \mathrm{C}$ transisyonu) tek nükleotid değişimi sonucu DraI restriksiyon enziminin kesim noktası kaybolmuştur. Böylece TTI AAA şeklinde olan DNA dizisi, TTECAAA şeklinde değişmiştir. $\mathrm{Bu}$ farklı kesim sonucu 440 bç’lik bantın kaybolması ile 552 ve 270 bç lik 2'li kesim profili elde edilmiştir (Şekil 4).

Bouga ve ark. (2005), Yunan ve Kibris bal arıs1 populasyonlarında ND5 gen bölgesinde DraI kesimi sonucunda iki kesim noktası olduğunu ve 429, 285 ve 108 bç uzunluğunda bantlar oluşturan tek bir haplotip elde ettiklerini bildirmişlerdir. Ivanova ve ark. (2010), Bouga ve ark. (2005) ile benzer olarak ND5/DraI bakımından aynı haplotipi tespit etmişlerdir. Özdil ve ark. (2012), Türkiye bal arısı populasyonlarında ND5/DraI bakımından bu çalışmada bulunan Tip 1 haplotipine benzer tek bir haplotip tespit etmişlerdir.

ND5 gen bölgesinin SwaI restriksiyon enzimi ile kesilmesi sonucunda tek bir kesim noktası bulunmuş ve 552 ve 270 bç'lik bant profili elde edilmiştir. Çalışılan tüm örneklerde ND5 lokusunda SwaI restriksiyon enzimi ile kesim sonucu tek bir haplotip tespit edilmiştir (Şekil 5).

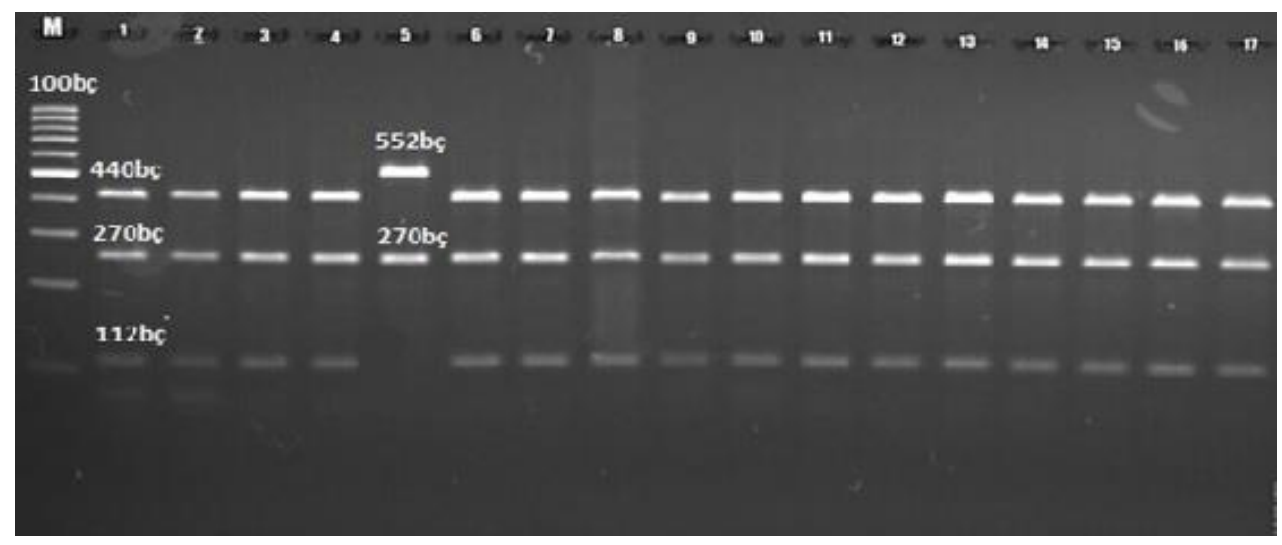

Şekil 4. ND5 gen bölgesinin DraI restriksiyon enzimi kesim sonucu.

1-4. ve 6-17. örnekler: Tip 1 haplotipi, 5. Örnek: Tip 2 haplotipi (Edirne/Meriç), M: Invitrogen ${ }^{\mathrm{TM}} 100$ bp DNA Ladder. (1-4. örnekler: Tekirdağ, 5-8. örnekler: Edirne, 9-12. örnekler: Kırklareli, 13-15. örnekler: Çanakkale, 16-17. örnekler: Gökçeada'dan alınmıştır.)

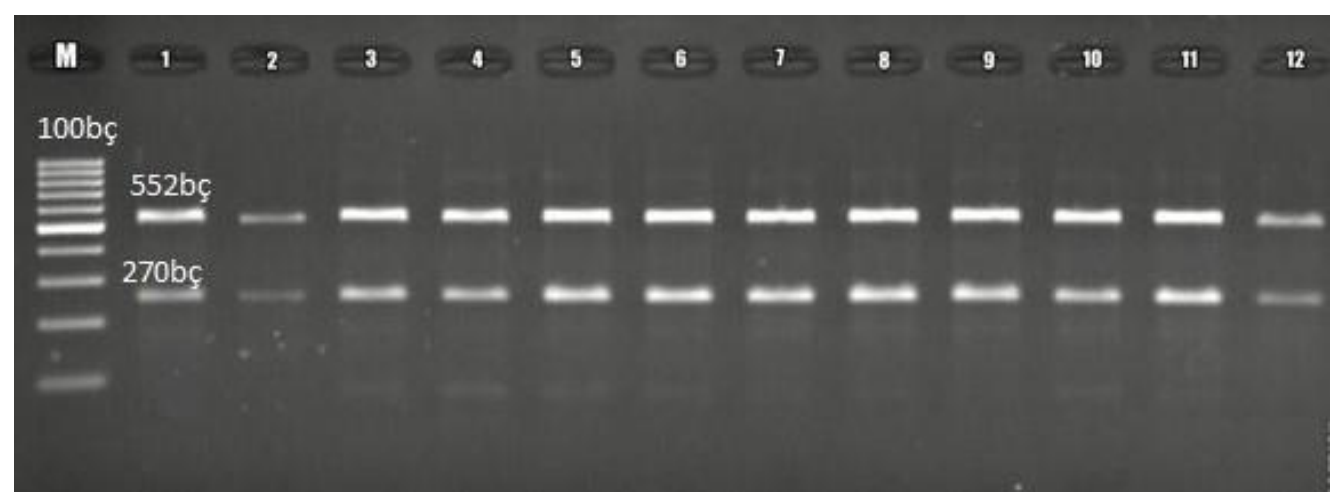

Şekil 5. ND5 gen bölgesinin SwaI restriksiyon enzimi kesim sonucu.

1-12 Örnekler: Tip 1 haplotipi, M: invitrogen ${ }^{\mathrm{TM}} 100$ bp DNA Ladder. (1-2. örnekler: Tekirdağ, 3-4. örnekler: Kırklareli, 5-7. örnekler: Edirne, 8-9.örnekler: Çanakkale, 10-11. örnekler: Gökçeada'dan alınmıştır.) 
ND5 gen bölgesinin MboII restriksiyon enzimi ile kesilmesi sonucunda tek bir kesim noktası bulunmuş ve 662 ve 160 bç'lik bant profili elde edilmiștir. Çalıșılan tüm örneklerde ND5 lokusunda MboII restriksiyon enzimi ile kesim sonucu tek bir haplotip tespit edilmiştir (Şekil 6).

$\mathrm{Bu}$ çalışmada incelenen bal arısı örneklerinde $16 \mathrm{~S}$ rDNA ve ND5 gen bölgelerinde PCR-RFLP yöntemi ile tespit edilen haplotipler ayrıca DNA dizi analizi ile incelenmiştir. 16S rDNA gen bölgesinin DNA dizi analizi sonuçları, NCBI Genbankasından alınan referans DNA dizileri, Kafkas (A. m. caucasica), İran (A. m. meda) ve Anadolu arısı (A. m. anatoliaca) ile birlikte filogenetik analize tabi tutulmuştur. DNA dizi analizi sonuçlarına göre oluşturulan Komşu Birleştirme Ağacında (Neigbour Joining, NJ), 16S rDNA/SwaI kesimi sonucu bulunan Tip 2 haplotipi (Tekirdağ/Çerkezköy), Anadolu arısı ile aynı kümede bulunurken, 16S rDNA/DraI kesimi sonucu bulunan Tip 2 haplotipi (Gökçeda/Zeytinlikköy) İran arısı ile aynı kümede yer almıştır (Şekil 7). Analiz edilen tüm Trakya Bölgesi bal arısı örneklerinde Tip1 haplotipi yaygın bulunan haplotip olarak tespit edilmiştir.

Trakya Bölgesi bal arısı örneklerinde ND5 gen bölgesinde PCR-RFLP yöntemi ile tespit edilen haplotiplerde ayrıca DNA dizi analizi de yapılmıştır. ND5 gen bölgesinin DNA dizi analizi sonuçları ile NCBI Genbankasından alınan referans Kafkas (A. $m$. caucasica), İran (A. m. meda) ve Anadolu arısı (A. m. anatoliaca) örnekleri ile oluşturulan Komşu Birleştirme Ağacında (Neigbour Joining, NJ) ND5/DraI kesimi sonucu bulunan Tip 2 haplotipi (Edirne/Meriç), Kafkas arısına yakın kümede yer almıştır (Şekil 8). Analiz edilen tüm Trakya örneklerinde Tip1 haplotipi yaygın bulunan haplotip olarak belirlenmiştir.

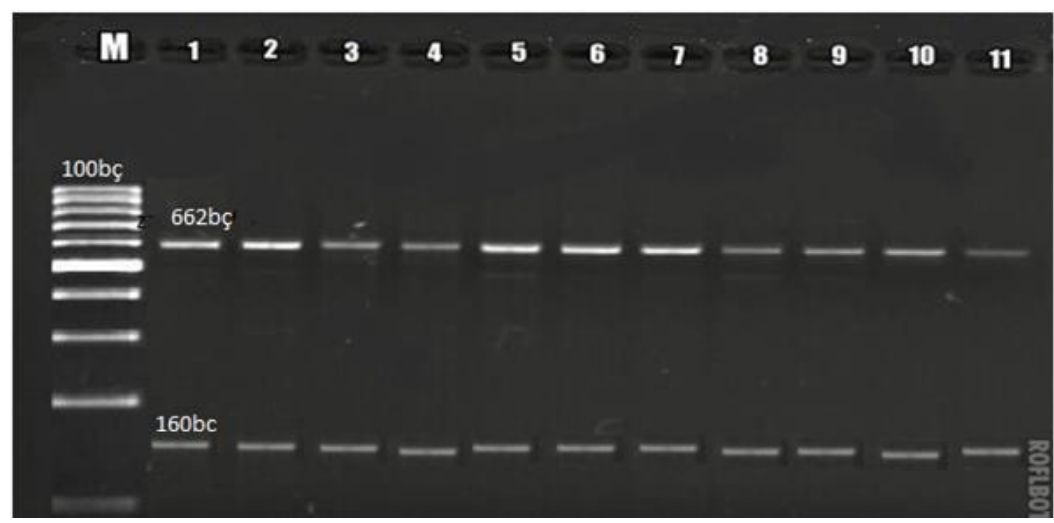

Şekil 6. ND5 gen bölgesinin MboII restriksiyon enzimi kesim sonucu.

1-11. örnekler: Tip 1 haplotipi M: invitrogen ${ }^{\mathrm{TM}} 100$ bp DNA Ladder. (1-2. örnekler: Tekirdağ, 3-4. örnekler: Kırklareli, 5-7. örnekler: Edirne, 8-9. örnekler: Çanakkale, 10-11. örnekler: Gökçeada'dan alınmıştır.)

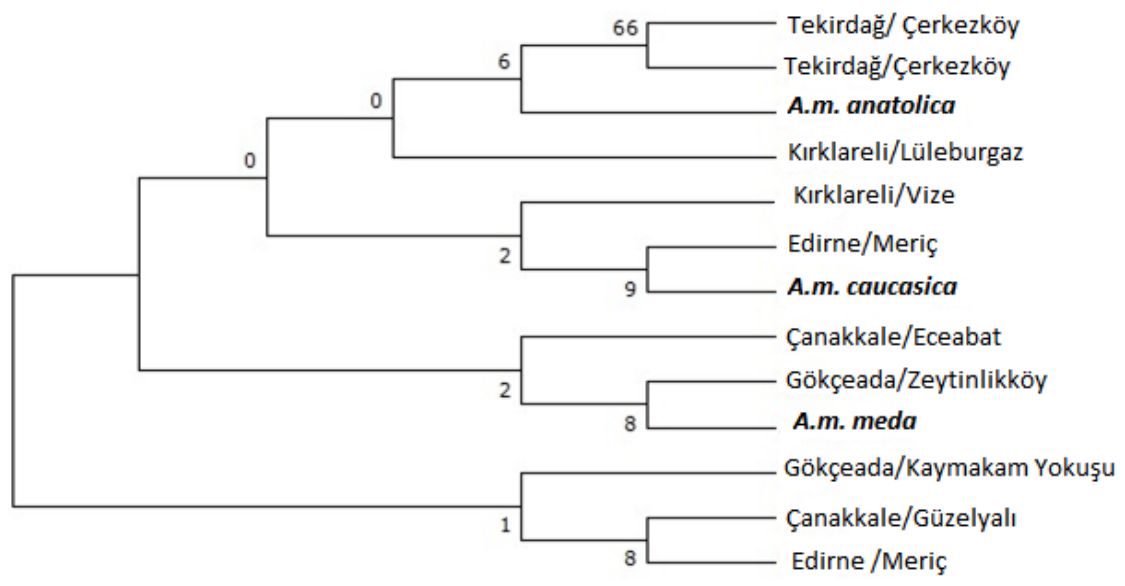

Şekil 7. 16S rDNA gen bölgesi DNA dizi analizi sonucu elde edilen Komşu Birleştime Ağacı 


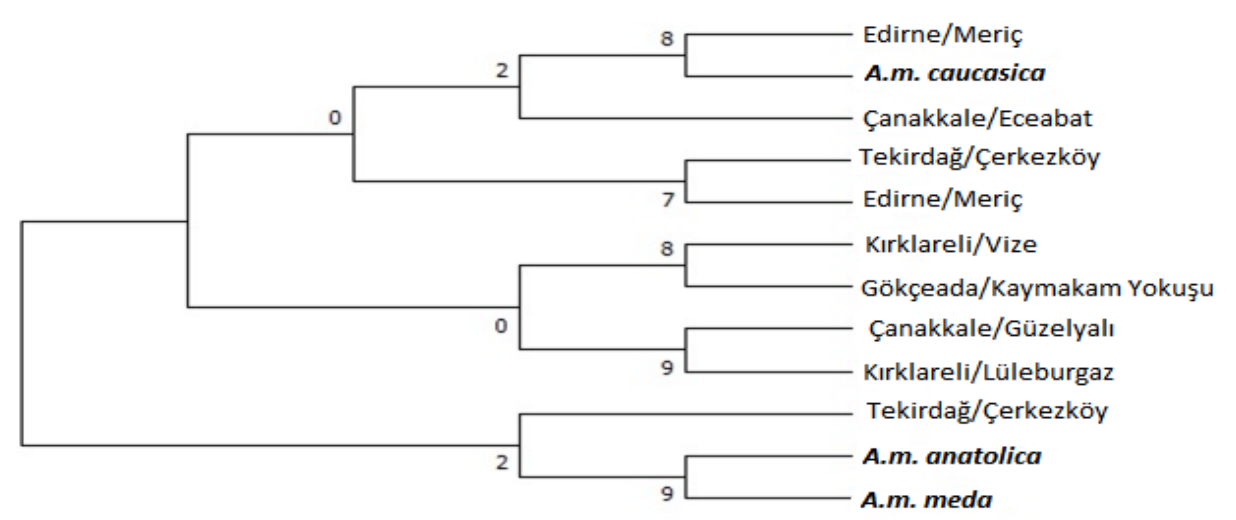

Şekil 8. ND5 gen bölgesi DNA dizi analizi sonucu elde edilen Komşu Birleştime Ağacı

\section{Genel Sonuç}

$\mathrm{Bu}$ araştırmada, Türkiye'nin Trakya Bölgesi'nin 4 ili (Tekirdağ, Kırklareli, Edirne ve Çanakkale/Gelibolu) ve Gökçeada'dan örneklenen bal arılarında mitokondriyel DNA molekülü bakımından genetik yapının tanımlanması, olası yeni haplotiplerin belirlenmesi ve farklı bölgelerde yetiştirilen populasyonlar arasındaki farklılıkların tespit edilmesi amaciyla $16 \mathrm{~S}$ ribozomal DNA (16S rDNA) ve NADH dehidrogenaz 5 (ND5) gen bölgeleri $D r a \mathrm{I}, M b o I I$ ve $S w a I$ restriksiyon enzimleri ile kesim (PCR-RFLP) ve DNA dizi analizi yöntemlerinden yararlanılarak araştırılmıştır. Söz konusu genler ve farklı enzimler ile kesim sonucu populasyonları ayırt etmede kullanılabilecek farklılıklar elde edilememiştir ancak 16S rDNA gen bölgesinin DraI ve SwaI restriksiyon enzimleri ile ND5 gen bölgesinin ise DraI restriksiyon enzimi ile kesimi sonucu varyasyon bulunmuş ve farklı haplotipler elde edilmiştir.

16S rDNA gen bölgesinin $\operatorname{DraI}$ restriksiyon enzimi ile kesimi sonucu tüm örneklerde Tip 1 haplotipi tespit edilirken, Gökçeada/Zeytinlikköy'den alınan bir örnekte Tip 2 haplotipi olarak ifade edilen yeni bir haplotip ilk kez bu çalışma ile ortaya konmuştur. 16S rDNA gen bölgesinin MboII restriksiyon enzimi ile kesimi sonucu tüm örneklerde tek bir haplotip (Tip 1) tespit edilmiş, bu enzim bakımından Trakya bal arısı populasyonlarında varyasyon bulunamamıştır. 16S rDNA gen bölgesinin SwaI restriksiyon enzimi ile kesimi daha önce çalışılmamıştır. $\mathrm{Bu}$ nedenle kesim sonucu elde edilen haplotipler ilk kez bu çalışmada ortaya konmuştur. 16S rDNA/SwaI restriksiyon enzimi kesimi sonucu tüm Trakya bal arısı örneklerinde Tip 1 haplotipi tespit edilirken, sadece Tekirdağ/Çerkezköy'den alınan iki örnekte Tip 2 haplotipi bulunmuştur.

Çalışılan bir diğer gen bölgesi olan ND5 geni, DraI, MboII ve $S w a$ I restriksiyon enzimleri ile kesilmiş ve sadece $\operatorname{DraI}$ restriksiyon enzimi ile kesim sonucu varyasyon tespit edilmiştir. Trakya bal arısı populasyonlarmda ND5/DraI restriksiyon enzimi bakımından Tip 1 haplotipi yaygın bulunan haplotip iken; Edirne/Meriç'ten alınan bir örnekte farklı bir kesim modeli tespit edilmiş olup, bu haplotip Tip 2 olarak ifade edilmiştir. DNA dizi analizi sonucu çizilen Komşu Birleştirme Ağacında Edirne/Meriç, A. m. caucasica ile yakın kümede yer almıştır. Buradan yola çıkarak Edirne/Meriç'ten alınan örneğin Kafkas orijinli olabileceği düşünülmektedir. Ayrıca ND5/DraI restriksiyon enzimi bakımından Tip II haplotipinin oluşmasina neden olan ND5 geninin 383. pozisyonda $\mathrm{T} \rightarrow \mathrm{C}$ transisyonunun Kafkas arı ırkına özgü bir nükleotid değişimi olup olmadığı ileride yapılacak ayrıntılı çalışmalarda incelenmeli ve eğer söz konusu nükleotid değişimi sonucu elde edilen kesim farklılığı, Kafkas arısına özgü bulunursa bu kesim farklılığının Kafkas bal arısının teşhis ve tespit edilmesinde genetik marker olarak kullanımı gündeme gelmelidir. ND5 gen bölgesinin $M b o I I$ ve $S w a I$ restriksiyon enzimleri ile kesimi sonucu tüm örneklerde tek bir haplotip (Tip 1) tespit edilmiş, Trakya bal arısı populasyonlarında varyasyon bulunamamıştır.

Bu çalışmada 16S rDNA ve ND5 gen bölgelerinin PCRRFLP ve DNA dizi analizi ile birlikte değerlendirilmesi sonucu Trakya Bölgesi bal arısı populasyonlarında elde edilen haplotipler ortaya konmuştur. Söz konusu bal arısı populasyonlarının büyük bir kısmı, benzer haplotipler içerisinde bulunmuştur. Az sayıda örnekte varyasyon tespit edilmiştir. Bu örnekler Gökçeada, Tekirdağ ve Edirne'den alınan az sayıda örneklerdir. Varyasyon bulunan örneklerin bir kısmının A. m. caucasica orijinli olabileceği tespit edilmiş̧ir. Bu durumun sebepleri olarak bölgeye zaman zaman yoğun bir şekilde Kafkas ana arısı getirilmesi ve gezginci arıcılığın neden olabileceği düşünülmektedir. Daha ayrıntılı örnekleme ve farklı 
restriksiyon enzimleri ve gen kombinasyonları ile çalışmalar yapılarak hem bu hipotez test edilmeli ve hem de Trakya bal arısı populasyonlarının genetik yapısı daha ayrınıtılı olarak tanımlanmalıdır.

\section{Kaynaklar}

Bouga M, Harizanis PC, Kilias G, Alahiotis S. 2005. Genetic divergence and phylogenetic relationships of honey bee Apis mellifera (Hymenoptera: Apidae) populations from Greece and Cyprus using PCRRFLP analysis of three mtDNA segments. Apidologie 36: 335-344.

Hall HG. 1990. Parental analysis of introgressive hybridization between African and European honeybees using nuclear DNA RFLPs. Genetics 125:611-621.

Ivanova EN, Petrov P, Bouga M, Emmanouel NG, Tunca RI, Kence M. 2010. Genetic variation in honey bee (Apis mellifera L.) populations from Bulgaria. Journal of Apicultural Science, 54: 51-62.

Kandemir İ, Kence M, Sheppard WS, Kence A. 2006. Mitochondrial DNA variation in honey bee (Apis mellifera L.) populations from Turkey. Journal of Apicultural Research and Bee World 45(1): 33-38.

Kekeçoğlu M, Bouga M, Harizanis P, Soysal MI. 2009. Genetic divergence and phylogenetic relationships of honey bee populations from Turkey using PCRRFLP's analysis of two mtdna segments. Bulgarian Journal of Agricultural Science 15 (6): 589-597.

Meixner, MD, Sheppard, WS, Poklukar, J. 1993. Asymmetrical distribution of a mitochondrial DNA polymorphism between 2 introgressing honeybee subspecies. Apidologie 24: 147-153.

Özdil, F, Aytekin, İ, İlhan, F, Boztepe, S. 2012. Genetic variation in Turkish honeybees Apis mellifera anatoliaca, A. m. caucasica, A. m. meda (Hymenoptera: Apidae) inferred from RFLP analysis of three mtDNA regions (16S rDNA-COI-ND5). European Journal of Entomology 109 (2): 161-167.

Palmer MR, Smith DR, Kaftanoğlu O. 2000. Turkish honeybees: genetic variation and evidence for a fourth lineage of Apis mellifera mtDNA. The Journal of Heredity 91 (1): 42-46.

Ruttner F. 1988. Biogeography and Taxonomy of Honeybees. Springer-Verlag. 193 p, Berlin.

Sheppard WS, Arias MC, Grech A, Meixner MD. 1997. Apis mellifera ruttneri, a new honey bee subspecies from Malta. Apidologie 28 (5): 287-293.

Smith DR, Brown WM. 1990. Restriction endonuclease cleavage site and length polymorphisms in mitochondrial DNA of Apis mellifera mellifera and A. m. carnica (Hymenoptera Apidae). Annals of the Entomological Society of America 83(1): 81-88.

Smith DR, Slaymaker A, Palmer M, Kaftanoğlu O. 1997. Turkish honeybees belong to the East Mediterranean mitochondrial lineage. Apidologie 28 (5): 269-274.

Ünal G, Özdil F. 2017. Genetic characterization of honey bees in Thrace region of Turkey using inter Cytochrome C oxidase subunit I and II genes. 2nd International Balkan Agriculture Congress. 16-18 May, Tekirdağ, s 395. 